\title{
Electroacupuncture at ST36 Relieves Visceral Hypersensitivity via the NGF/TrkA/TRPVI Peripheral Afferent Pathway in a Rodent Model of Post-Inflammation Rectal Hypersensitivity [Erratum]
}

\author{
Chen Y, Cheng J, Zhang Y, Chen JDZ, Seralu FM. \\ J Inflamm Res. 2021;14:325-339. \\ This error was introduced by the Editorial staff during the \\ publication process.
}

The authors have advised there is an error in the author list on page 325. The author name "Florin M Seralu" should read "Florin M Selaru".

\section{Publish your work in this journal}

The Journal of Inflammation Research is an international, peerreviewed open-access journal that welcomes laboratory and clinical findings on the molecular basis, cell biology and pharmacology of inflammation including original research, reviews, symposium reports, hypothesis formation and commentaries on: acute/chronic inflammation; mediators of inflammation; cellular processes; molecular mechanisms; pharmacology and novel anti-inflammatory drugs; clinical conditions involving inflammation. The manuscript management system is completely online and includes a very quick and fair peerreview system. Visit http://www.dovepress.com/testimonials.php to read real quotes from published authors. 